\title{
19th Century mechanical models of eye movements, Donders' law, Listing's law and Helmholtz' direction circles
}

\author{
H.J. SIMONSZ ${ }^{1} \&$ I. DEN TONKELAAR ${ }^{2}$ \\ ${ }^{\prime}$ Netherlands Ophthalmic Research Institute, Amsterdam, The Netherlands* \\ ${ }^{2}$ Keeper, Ophthalmic Collection of the former Royal Netherlands Ophthalmic Hospital
}

Key words: Listing's law, Donders' law, pseudotorsion, ocular counterrolling, ophthalmotropes

\begin{abstract}
Donders, Ruete, von Graefe, von Helmholtz, Listing, Volkmann and many others have provided the broad outline of an answer to the question how the eye rotates during eye movements. Many mechanical models of eye movements, ophthalmotropes, have been constructed and studied in the nineteenth century. These models have primarily served to explain Donders' and Listing's Laws on the nature of eye movements. As both Donders' Law and Listing's Law are easier to understand when seen against the background of the coordinate systems used to describe eye movements, all of the coordinate systems currently in use in the diagnosis and treatment of strabismus are described. In addition, the reader is introduced to a coordinate system based on von Helmholtz' direction circles, circles describing the direction of the horizontal and vertical retinal meridians in all positions of gaze.
\end{abstract}

\section{Donder's Law}

'De werking en verrigting der oogspieren behoort tot die onderwerpen, welke door physiologen ten allen tijde met ijver en een zekere voorliefde zijn behandeld, en deze ijver vond in de voor eenige jaren zooveel gerucht makende operatiën tegen het scheelzien en de bijziendheid overvloedig voedsel.' (The action and effect of eye muscles is one of the subjects that have always been treated by physiologists with zeal and predilection, and this zeal has been nourished by the operations for squint and for myopia that caused so much uproar some years ago.) This first sentence of F.C. Donders' first article on eye muscle mechanics applied in 1846 as it applies today. Donders, Ruete, von Graefe, von Helmholtz, Listing, Volkmann and many others have provided the broad outline of an answer to the question how the eye rotates during eye movements. Donders had become interested in eye movements when he translated Professor C.G.T. Ruete's 'Lehrbuch der Ophthalmologie' (1846). He was a young doctor in the military in Utrecht, earned 800 guilders a year and, hence, did translation work to earn extra money.

\footnotetext{
*This article is part of a thesis submitted to the University of Giessen (Simonsz, 1990).
} 
Ruete (1845) had developed in Scharmbeck the first mechanical model of the eye and its muscles. He called it an 'ophthalmotrope'.

Ruete also studied the rotation of his own eye about the visual axis. He was able to observe the rotation of his own eye about the visual axis by using an afterimage with the form of a + cross. A green afterimage was produced by looking at a red cross for a long time. He then looked at a screen in front of him to see whether the afterimage remained vertical when he looked right, left, up or down. Donders repeated these experiments and found that the afterimage cross tilted, when he looked in tertiary positions of gaze (i.e. right-up, right-down, left-up or left-down): He found that the amount of torsion depended upon the amount of elevation or depression and right or left gaze (Donders' Law).

In 1848 a German edition of Donders' work appeared which drew von Helmholtz' attention. He was very enthusiastic about Donders' discovery and proposed to call the definition of pseudotorsion 'Donders' law'. The reason for the tilt had not been recognized by Donders, however, it was von Helmholtz who explained the reason for pseudotorsion.

\section{The reason for pseudotorsion}

Pseudotorsion is caused by the fact that, in tertiary positions of gaze, the vertical retina meridian does not coincide with a vertical line in space, nor does the horizontal retina meridian coincide with a horizontal line in space. The reason for this discrepancy is that horizontal and vertical are defined according to the coordinate system used. To illustrate this point: If the reader is sitting in front of one of the four walls of the room he is in, let him for a moment look at the left upper hand corner of this wall. The reader will perceive the left upper hand 90 -degree corner of a wall in front of him as being larger than $90 \mathrm{deg}$. What, in this case, is horizontal and what is vertical? It is clear that the angle between the horizontal and the vertical retinal meridians is perceived as 90 degrees at all times, no matter what the direction of gaze is. Hence, the afterimage cross cannot coincide with the left upperhand corner of the wall in front of us. The rays of the left upper hand corner are horizontal and vertical in space but, as the angle is perceived as larger than 90 degrees, the rays of the angle cannot possibly coincide with horizontal and vertical retina meridians. In fact, both rays of the angle, projected on the retina, deviate with a small angle from the horizontal and vertical retinal meridian, one clockwise and one anticlockwise. This small angle is called pseudotorsion.

Summarizing, pseudotorsion results from the coordinate system employed or, in other words the reference that one chooses to be vertical or horizontal (Roelofs 1934, 1954). 
The polar coordinate system and Listing's Law

The only coordinate system for describing eye rotations that does not have these flaws is the polar coordinate system. In a polar coordinate system the position of the eye is also determined by two angles: One angle defines the direction of eye movement out of the primary position and a second angle defines the angle of eye movement out of the primary position. In this coordinate system, all tertiary positions of gaze are reached by simple rotation about a single axis. This principle was invented by Professor J.B. Listing, a good friend of Professor Ruete, who had participated with Ruete in the Göttinger Studien with a booklet on entoptic phenomena and cataract (1845).

Ruete (1853) therefore called this principle Listing's Law: 'Aus der oben angegebenen normalen Stellung (Anfangsstellung, Primärstellung) des Auges wird das Auge in irgend eine andere, secundäre, durch die Cooperation der sechs Muskeln in der Weise versetzt, dass man sich diese Versetzung als das Resultat einer Drehung um eine bestimmte Drehungsaxe vorstellen kann, welche jederzeit, durch das Augencentrum gehend, auf der primären und secundären Richtung der optischen Axe zugleich senkrecht steht, so dass also jede secundäre Stellung des Auges zur primären in der Relation steht, vermöge welcher die auf die optische Axe projicirte Drehung $=\mathrm{O}$ wird. Diesem Princip zufolge lässt sich aus der bekannten Lage der drei auf je zwei antagonistische Muskeln bezüglichen Drehungsaxen für jede gegebene Secundärstellung des Auges der Wirkungsbetrag jedes Muskels, d.i. die Grösse seiner Verkürzung durch Rechnung bestimmen. Unter den vielfachen Consequenzen dieses Princips verdient die hervorgehoben zu werden, dass nämlich das Auge beim Uebergange aus einer secundären Stellung in eine andere eine ihrer Grösse nach bestimmbare Drehung um seine optische Axe erfährt, welche nur in dem besonderen Fall null ist, wenn die drei Richtungen der optischen Axe in der primären und in den beiden secundären Stellung in einer Ebene liegen' (in short, all secondary and tertiary positions of gaze can be reached by rotation about a single axis that is perpendicular to the primary position of gaze and to the new position of gaze ... Among the many consequences of this principle, one needs particular emphasis, namely, that the eye will rotate about its optical axis in eye movements from one tertiary to another tertiary position of gaze, this rotation being zero only when the two tertiary positions of gaze and the primary position of gaze are all in a single plane.)

The Ophthalmic Collection of the former Royal Netherlands Ophthalmic Hospital has a copper model that illustrates this principle beautifully (Fig. 1). The name of the place of manufacture, Halle, is engraved in the model. 


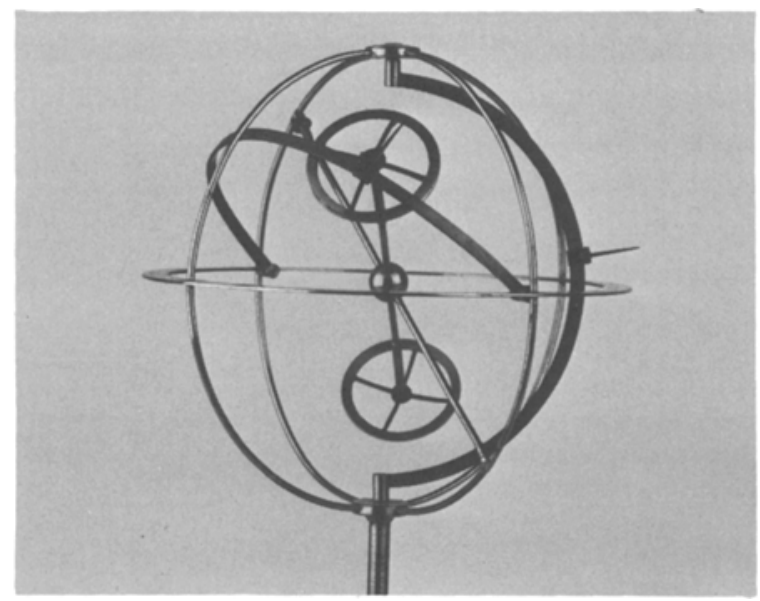

Fig. 1. Ophthalmotrope from the Ophthalmologic Collection of the former Royal Netherlands Ophthalmic Hospital in Utrecht, probably sent by Ruete to Donders $( \pm 1852)$, demonstrating Donders' and Listing's Laws: all secondary and tertiary positions of gaze can be reached by rotation about a single axis that is perpendicular to the primary position of gaze and to the new position of gaze. The primary position of gaze is at the left in the figure. The eye is represented by a small globe in the center of the model. Two wheels with spokes (representing the horizontal and vertical retina meridians) are mounted on the tips of an axis representing the position of gaze. This position-of-gaze axis can tilt about the oblique axis representing an axis in Listing's plane. At the front of the model (left in the picture) an arc representing a horizontal meridian in space can be tilted upward: one can see that the horizontal retina meridian is tilted relative to the meridian arc (Donders' pseudotorsion). At the back of the model, a vertical arc, representing a vertical meridian in space, can be turned together with the second spoked wheel: Donders' pseudotorsion is found to occur in the opposite direction. The horizontal and vertical arc meridians correspond to the way straight horizontal and vertical lines in space are perceived by the eye in the center of the model: In the experiments of Donders, he compared horizontal and vertical retina meridians with horizontal and vertical lines on a wall in front of him, these are represented in this model by the meridian arcs.

Halle is about $30 \mathrm{~km}$ from Leipzig, so it was probably Ruete who sent this model to Donders.

In Ruete's first ophthalmotrope (1845) the model eye was suspended in gimbals, i.e. the model eye rotated in a ring that itself could rotate about an axis that was perpendicular to the first axis, this method of suspension having been invented by Cardano in the sixteenth century. An improved version of his ophthalmotrope, presented by him in Leipzig in 1857, no longer employed suspension with gimbals. The globe was simply pulled against a ring with screws by the 'muscles'. It can now be seen why Ruete did not employ a gimbal suspension in the second version of his ophthalmotrope: this kind of globe suspension will not bring the eye in a tertiary position that complies with Listing's Law: Pseudotorsion will occur in 


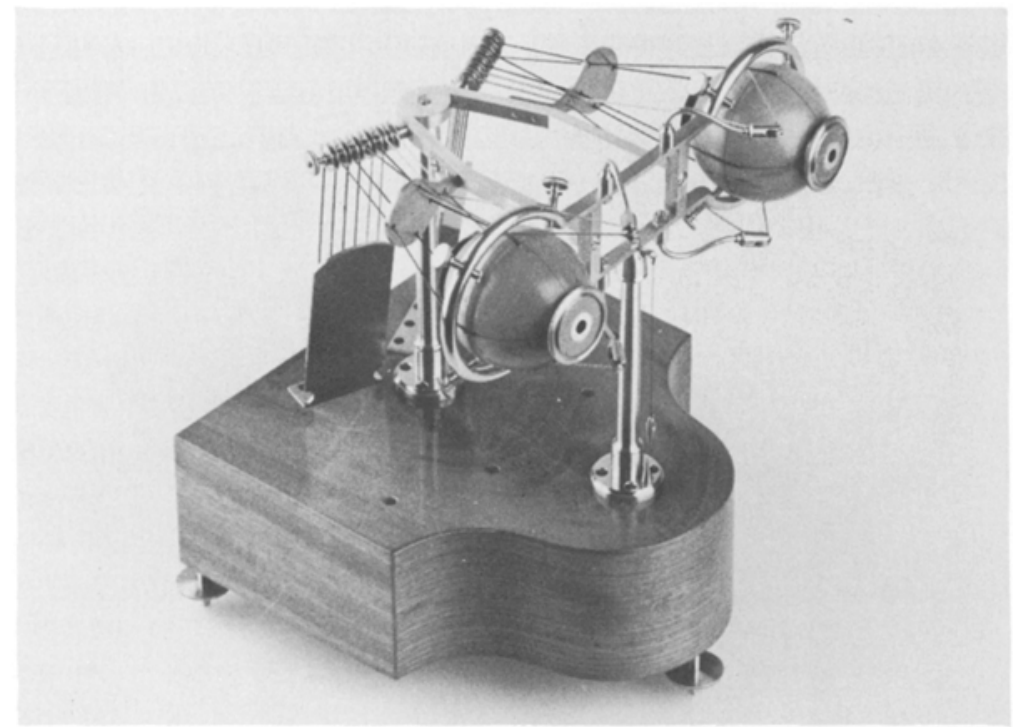

Fig. 2. Ruete's second ophthalmotrope. Note that the eyes are not suspended in gimbals like in Ruete's first ophthalmotrope, because then Listing's Law would be violated.

tertiary positions of gaze. Ruete wrote that the ring with screws supporting the model eye represented the 'fat pad behind the eye, the nutshell in which the eye was suspended', quite a modern concept for his time. Donders (1870) later presented his own ophthalmotrope to illustrate Donders' Law. In this model he used gimbal suspension on purpose, to make the pseudotorsion available. This ophthalmotrope was equipped with a camera obscura, to obtain an image of, for instance, the left upper hand corner of the wall in front of us. This image was to be compared with the retinal meridians, which were represented by 4 copper bars surrounding the camera obscura.

\section{The reason for Listing's Law}

What is the reason of the existence of Listing's Law or, in other words, why is there a primary position, from which all other eye positions can be reached by simple rotation about a single axis or, in other words, why isn't the primary position in left upper gaze for instance?

Von Helmholtz compared Listing's Law with the minimal energy condition in physics (1863). Applying this principle in a broader sense, one could say that Listing's law is probably the consequence of the fact that the primary position is the average of all eye positions during the day, that most eye movements are directed radially from or to the primary position and that rotations about a single axis are easier to perform than rotation about 


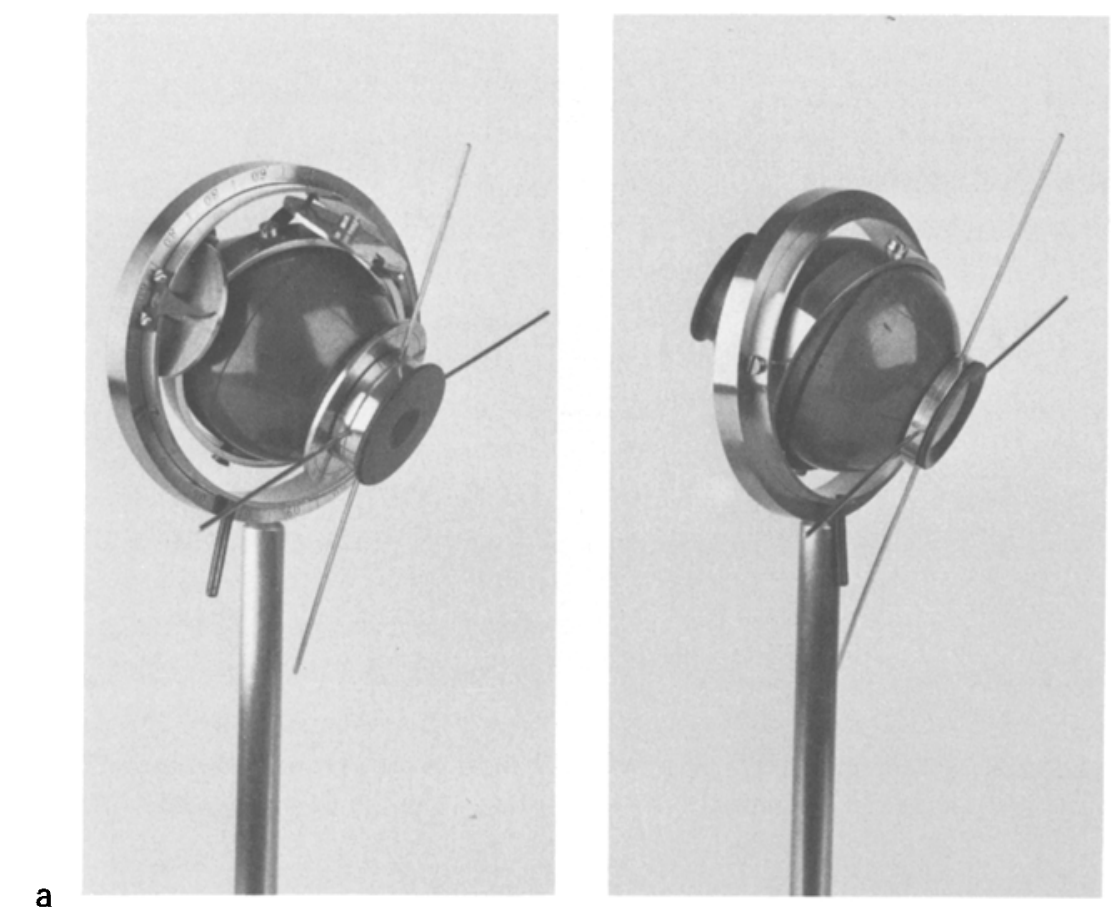

Fig. $3 a$ and $b$. Models to demonstrate and to quantify Donders' pseudotorsion, from the museum of the former Royal Netherlands Ophthalmic Hospital in Utrecht. In these models Donders used gimbal suspension on purpose, to make the pseudotorsion visible (gimbal suspension results in globe rotations that do not conform to Listing's Law). The final version (Fig. 3b) was described by Donders in 1870 . The ophthalmotropes were equipped with a camera obscura, to obtain an image of, for instance, the left upper hand corner of the wall in front of us; this image was to be compared with the retinal meridians, which were represented by 4 copper bars surrounding the camera obscura ( 2 are broken off). The eye rotated in the

two axes or about an axis that changes during the movement. Eye movements from tertiary positions to other tertiary positions do occur, but are less frequent and do not occur predominantly in down-, up-, right- or left-gaze. During eye movement from one tertiary to another tertiary position, Listing's law is fulfilled only if the rotation takes place about an axis that is tilted to Listing's plane by half the angle between the momentary tertiary position and primary position (von Helmholtz 1863): hence an axis that can change during the movement.

The primary position (Ruete 1853), as determined with afterimages (Hering, 1868, p. 74-83) varies over time (von Helmholtz 1910; Schubert 1927), is in down-gaze for convergence (Donders 1876 see below) and varies with head position (Fisher 1922). 
b

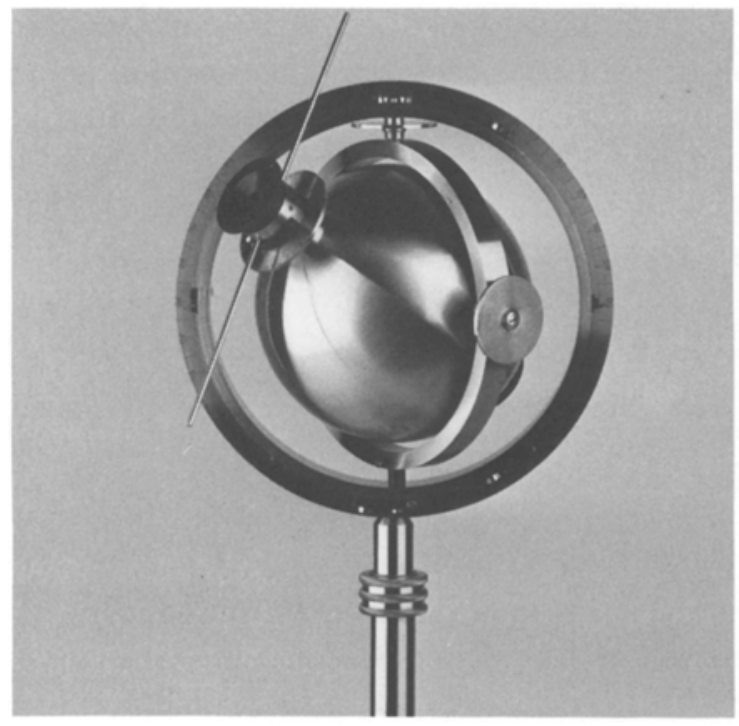

inner ring, and the inner ring rotated in the outer ring of the gimbal suspension, the primary and secondary axes of rotation being perpendicular. The outer ring is in Listing's frontoparallel plane' and it could rotate in its sleeve-like circular holder, so that the primary axis of rotation could tilt within Listing's plane. Hence, a tertiary position of gaze could be, incorrect$1 y$, reached by rotation about the primary horizontal and secondary vertical axes (resulting in pseudotorsion) or by tilting the primary axis of rotation in Listing's plane and subsequent rotation about the primary axis only (in compliance with Listing's Law).

\section{Ocular counterrolling}

Donders initially assumed that all rotation of the eyes about the optic axis, was pseudotorsion. The existence of true rotation about the optic axis, 'ocular counterrolling', was denied by him. Ocular counterrolling is a small counterrolling movement of both eyes about the visual axis when the head is tilted towards either shoulder, caused by the otolith reflex. True ocular counterrolling had already been described in 1786 by John Hunter, but had subsequently been overestimated by Hueck (1838), who thought that it fully compensated for up to 28.25 degrees of head-tilt to either shoulder. Actually, Hueck had only seen, not measured, the torsional nystagmus when tilting the head of another person from shoulder to shoulder. Then he measured, in an anatomical study, the distance that the superior oblique tendon could be pulled out of the trochlea, which was $5.5^{\prime \prime}$. He erroneously assumed that the superior oblique muscle had torsional action, exclusively, and given the diameter of the eye he estimated the maximum amplitude of 
torsional eye movement to be 56.5 degrees. (In more recent measurements, the actual amplitude of ocular counterrolling was found to be $5.64 \pm$ s.d. $2.57 \mathrm{deg}$ on $50 \mathrm{deg}$ head-tilt either way in 55 normal eyes by Nelson and Cope (1971), we found $5.53 \pm$ s.d. $1.95 \mathrm{deg}$ on $45 \mathrm{deg}$ head-tilt either way in 32 normal eyes (Simonsz 1984).

Ruete and Volkmann initially believed Hueck (von Graefe 1854), but later denied the existence of true ocular counterrolling when pseudotorsion was first described by Donders, and the amplitude of ocular counterrolling claimed by Hueck was not found. Hence, Donders' denial of the existence of true ocular counterrolling was supported by von Graefe (1854) and von Helmholtz (1863), but all had to revoke later (Donders 1875), when ocular counterrolling was rediscovered by Javal in 1866 .

Ocular counterrolling is accomplished by the concerted action of vertical rectus and oblique eye muscles. The superior rectus and superior oblique muscles of one eye, and the inferior rectus and inferior oblique muscles of the other eye contract, whereas their antagonists relax. This differential use of eye muscles, depending on head-tilt to either shoulder, has important consequences for patients with a palsy of the trochlear nerve that innervates the superior oblique eye muscle.

A patient with a trochlear nerve palsy will prefer a head tilt that confers ocular counterrolling such that the paretic muscle is not needed. Under these circumstances the angle of squint is small and double vision is absent. On head tilt towards the contralateral shoulder the angle of squint gets very large. This principle has been formulated by Nagel (1871), first applied clinically by Baumeister (1874), and elaborated by Hoffmann and Bielschowsky (1900). (Baumeister was a lesser known pupil of Donders; in the same article, however, he also described the dependence of latent nystagmus upon the direction of gaze for the first time!)

\section{Excyclotropia on convergence}

A third kind of torsion that has confused investigators is excyclotropia on convergence. Excyclotropia (vertical retina meridians tilting clockwise in the right eye and anti-clockwise in the left eye as seen from the patient's side) on convergence was found by Hering (1868), Donders (1876), Landolt (1876), Allen (1954) and others. We also found it to occur during voluntary convergence using a double-looped scleral search coil (Simonsz and Zee, unpublished results). Why should excyclotropia occur during convergence? The most likely reason was formulated by Donders (1876): Convergence occurs during near vision and near vision is done mostly in down-gaze. If the primary position for near vision is in down-gaze (for the same reason as why 


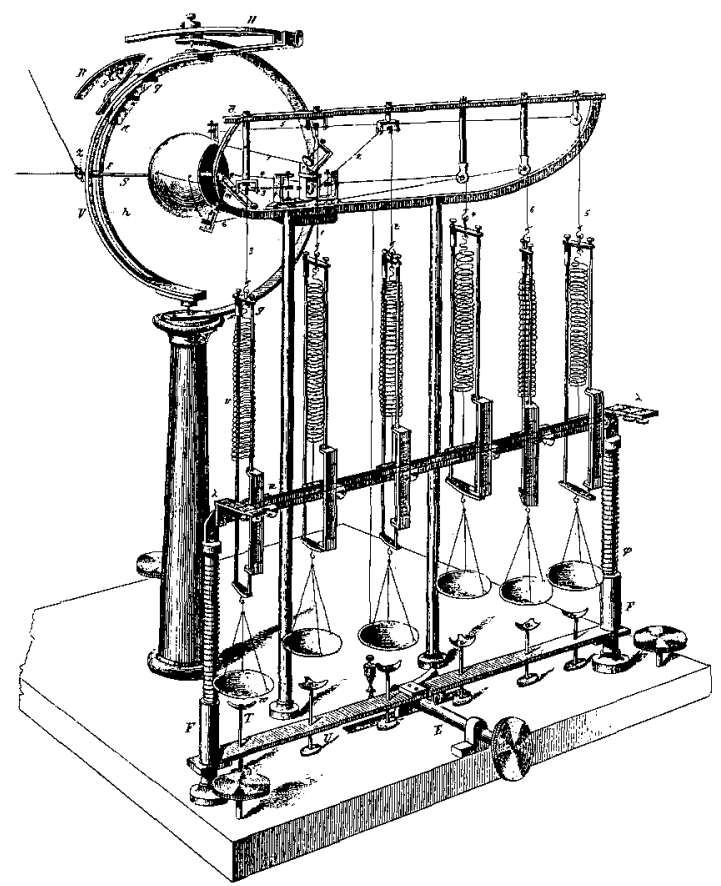

Fig. 4. Wundt's ophthalmotrope (1862). Muscle forces were represented by weights and springs.

the primary position for far gaze is approximately ahead, as discussed above) excyclotropia will occur when converging from gaze ahead. One can calculate and extrapolate the primary position for near vision from the excyclotropia that occurs during convergence from gaze ahead.

Only when converging the eyes by more than $10 \mathrm{deg}$, corresponding to a target distance of less than $35 \mathrm{~cm}$, excess excyclotropia has been found to occur, not accounted for by assuming a lower primary position for downgaze, but more than 10 degrees of convergence is of course a very unnatural condition.

\section{Wundt's ophthalmotrope}

The most sophisticated model of the nineteenth century was, no doubt, that made by Wundt in Heidelberg, 'ein künstliches Augenmuskelsystem zur Untersuchung der Bewegungsgesetze des menschlichen Auges im gesunden und kranken Zustande' (1862).

Whereas Ruete's model used anatomical variables only, Wundt's model also used physiological variables as muscle forces, represented by springs 
and weights. Remarkable in his analysis is that the spring constants of his model muscles were directly related to the cross-sectional area of the muscle and inversely related to the length of the muscle, as determined in postmortem studies. As a matter of fact, Donders (1848) had already measured the weights of the muscles to determine their relative force. (He found for human eye muscles that were dried at $100 \mathrm{deg} \mathrm{C}$ after removal of the tendon: $0.072,0.0725,0.0603,0.075,0.032$ and $0.0265 \mathrm{~g}$ for lateral, medial, superior and inferior rectus muscles, and superior and inferior oblique muscles, respectively.) In his article, Wundt (1862) presented the changes of muscle length, force and other parameters in 20/20 deg secondary and tertiary positions of gaze.

\section{Coordinate systems for describing eye movements}

In the coordinate system used most commonly in the diagnosis and treatment of squint, first the horizontal angle of a particular gaze position is described, and then the vertical angle (Fig. 5a-b, middle-left). This coordinate system was first employed by Fick (1854). It is an isoazimuth and isolatitude system, similar to the coordinate system used to designate a place on earth and similar to the system used in the Major Amblyoscope and Synoptometer. Its great disadvantage is that, in tertiary positions of gaze, an angle designated, for instance, ' 30 degrees' is larger vertically than horizontally. (For comparison: on earth the distance between one of the latitude circles and the equator is the same everywhere, whereas the distance between the vertical meridians decreases towards the poles).

Imagine that the coordinate system used to describe eye positions is drawn onto a globe. The observer is in the center of the globe. Imagine that the observer is looking from the center of the globe onto some point on the equator of the globe, and designate this point the primary position. Although the angles of the intersections of the latitude circles and the vertical meridians are all perceived by the observer as rectangular, the directions of the latitude circles and the vertical meridians will, nevertheless, not coincide with the horizontal and vertical meridians of the retina of the observer, they will both be tilted (Donders' law, 1846). If this coordinate system (Fig. 5a, middle left) were projected onto a screen in front of the observer, it would consist of vertical lines (projections of meridians) and horizontal hyperbolas (projections of latitude circles) (Fig. 5b, middle left).

The problems described above would be solved by using a polar coordinate system (Fig. 5a-b, middle right). Here, one angle defines the direction of eye movement and a second angle defines the amount of eye movement out of the primary position, following Listing's Law (Ruete 1853), that 'all 
secondary and tertiary positions of gaze can be reached by rotation about a single axis that is perpendicular both to the primary-position gaze direction and to the new gaze direction. However, the trigonometric calculations get very complex when one uses this system and angles of squint would have to be expressed in a totally different way.

Von Helmholtz $(1863,1910)$ also used a isolatitude-isoazimuth coordinate system, but used isolatitude horizontally and isoazimuth vertically (Fig. 5, top left), the reverse of Fick's system. (An equivalent of this coordinate system on earth would be to have the northpole in Columbia and the southpole in Indonesia.) He argued that the trigoniometric calculations were simpler using this system, when shifts in the reference point, the primary position, occurred: The primary position (Ruete 1853), as determined with afterimages (Hering, 1868, p. 74-83) varies over time (von Helmholtz 1910; Schubert 1927), is in down-gaze for convergence (Donders 1876) and varies with head position (Fisher 1922).

The angles between the horizontal meridians and vertical latitude circles in the system of von Helmholtz are also perceived as rectangular by the observer at the center of the globe but, again, the directions of the horizontal and vertical lines do not coincide, in tertiary positions of gaze, with the horizontal or vertical meridian of the retina of the observer: They are now both tilted the other way.

In a coordinate system that is isoazimuth both ways (meridians both horizontally and vertically on the globe or, projected onto a screen, straight horizontal and vertical lines), the angles between the horizontal and vertical lines are perceived by the observer as larger than $90 \mathrm{deg}$ (Fig. 5a-b, bottom left). An example of the use of this coordinate system is the 'Tangentenskala', a frontoparallel screen with straight horizontal and vertical lines on it, introduced by Harms (1941).

Hess (1916) introduced a coordinate system with isolatitude horizontally and vertically (Fig. 5a-b, top right) that became very popular as the 'Hess screen'. It is often used for measurements of the angle of squint in cases of eye muscle palsy. However, the angles between the horizontal and vertical lines of the Hess screen are perceived by the observer as smaller than $90 \mathrm{deg}$. Kolling and Simonsz (1986) assumed that between the two latter coordinate systems there should be another where all angles would be perceived by the observer as rectangular.

They then re-invented a system based on 'direction circles' (Fig. 5a-b, bottom right). The 'direction circles' represent the direction of the horizontal and vertical meridians of the retina in tertiary positions of gaze (von Helmholtz 1910). When an observer moves his eyes, from some tertiary position, constantly in the direction of the retinal horizontal or vertical meridian, the axis of rotation is neither in Listing's plane (isolatitude), nor 

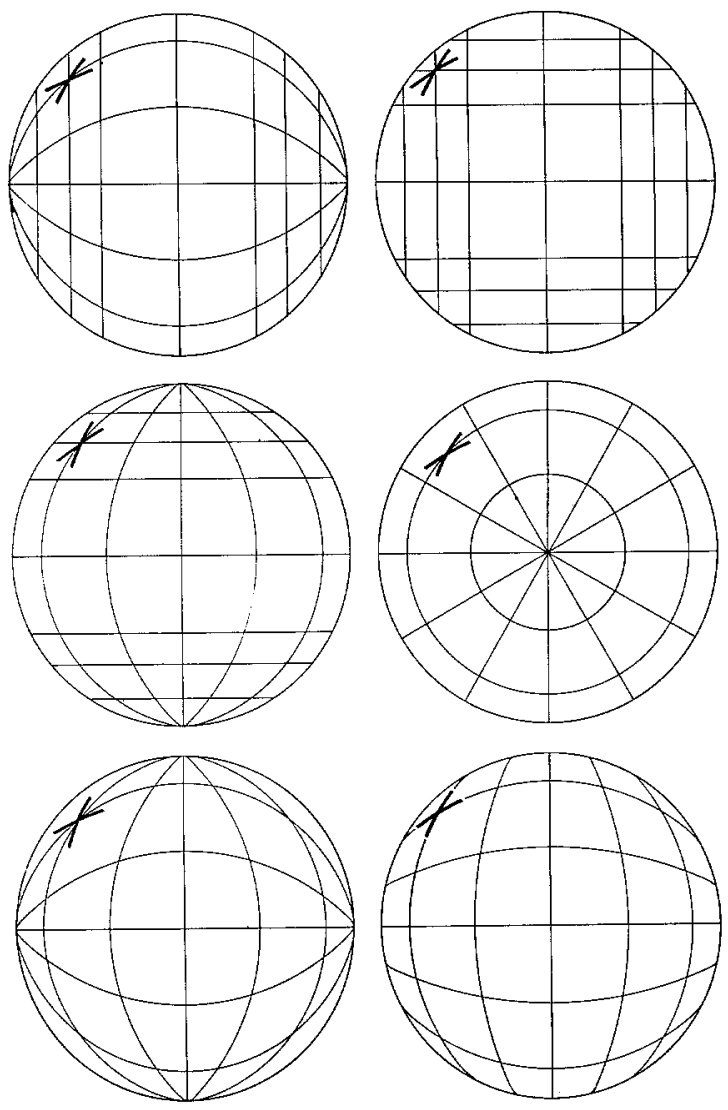

Fig. $5 a$.

is the axis of rotation perpendicular to the direction of gaze (isoazimuth). The axis of rotation is between these two (Fig. 6). Such an axis is the only possible single axis that the eye can rotate about, going from one tertiary position to another tertiary position and complying with Listing's Law. Now a curious mathematical peculiarity of direction circles is that all direction circles go through the 'occipital point' (von Helmholtz 1910). The occipital point is a point behind the observer. The occipital point is exactly in the direction opposite to the primary position.

Now, for construction of the coordinate system, consider only those direction circles that have either a common horizontal or a common vertical tangent in the occipital point. A series of vertical circles and a series of horizontal circles result (Fig. 7). The direction circles will represent the direction of the horizontal and vertical meridians of the retina in tertiary 

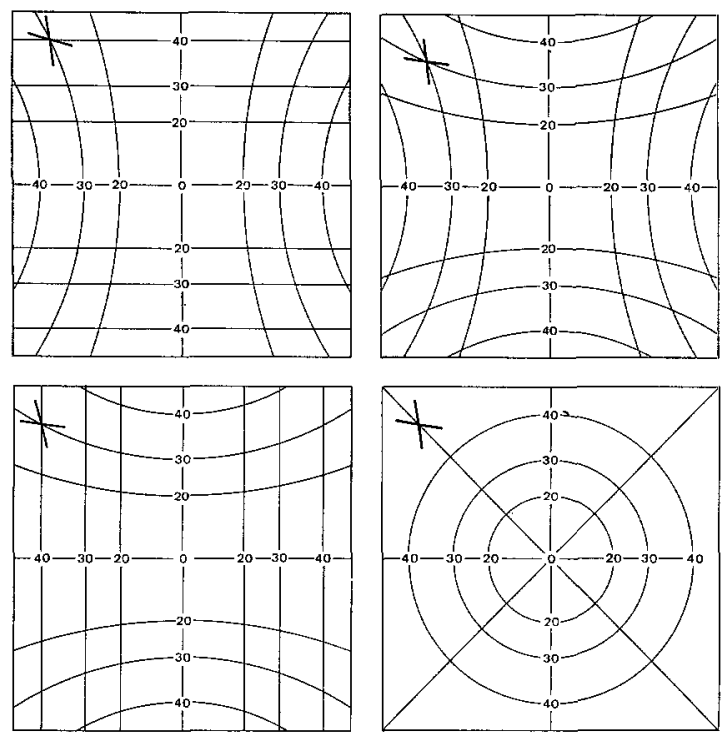

Fig. $5 b$.
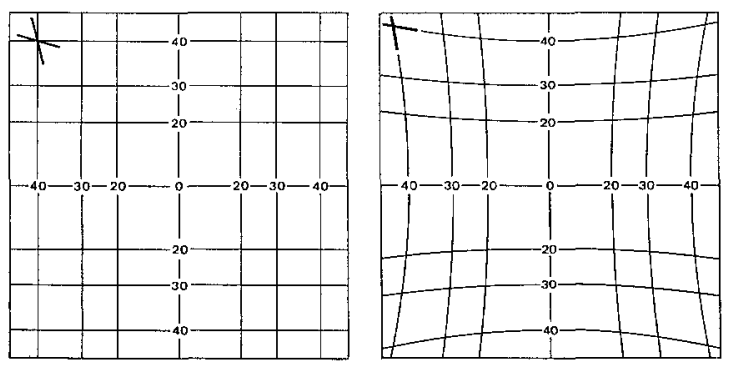

Fig. $5 a$ and $b$. The six coordinate systems describing eye movements, depicted on a globe (a) and their projections on a frontoparallel screen (b). The observer is at the center of the globe. In each figure, the direction of the horizontal and vertical meridian of the retina is represented by a bold cross. Upper left: the system used by von Helmholtz $(1863,1910)$ in his eye-movement calculations: isolatitude horizontally and isoazimuth vertically. Middle left: the system used by Fick (1854), isoazimuth horizontally and isolatitude vertically, the coordinate system used on earth, in the Synoptometer and in the Major Amblyoscope. Lower left: the system used by Harms (1941), isoazimuth both horizontally and vertically. Upper right: the systems used by Hess (1916), isolatitude both horizontally and vertically. Middle right: the polar coordinate system. Lower right: the coordinate system proposed by Kolling and Simonsz to be used in strabismus diagnostics, based on the 'direction circles'. The 'direction circles' represent the direction of the horizontal and vertical meridians of the retina in tertiary positions of gaze (von Helmholtz, 1910). Note that the horizontal and vertical meridians of the retina (cross) deviate from the horizontal and vertical lines in all coordinate systems (Donders' Law), except in the direction-circle coordinate system. The direction-circle coordinate system is preferable to the other systems because (1) the direction of the lines represent true horizontal and vertical in tertiary positions of gaze, (2) all intersections are perceived by the observer as rectangular, (3) it is free of Listing's pseudotorsion and (4) the artefact vertical or horizontal deviations that occur using the Major Amblyoscope or Synoptometer, when there is a large horizontal and vertical angle of squint, are avoided. 


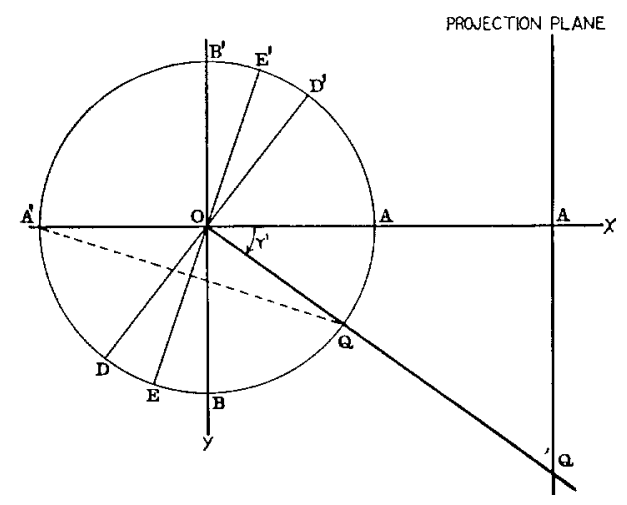

Fig. 6. Axis of rotation in eye movement along a 'direction circle'. The 'direction circles' represent the direction of the horizontal and vertical meridians of the retina in tertiary positions of gaze (von Helmholtz 1910). The observer is at point $O$, looking in primary position at point $\mathbf{A} . \mathbf{B}^{\prime}$ is left, $\mathbf{B}$ is right of the observer. If the observer first looks at point $Q$ and then shifts his gaze upwards following the direction of the vertical meridian of his retina, his eyes do not rotate about $\mathrm{B}^{\prime} \mathrm{B}$ or about $\mathrm{D}^{\prime} \mathrm{D}$, they rotate about $\mathrm{E}^{\prime} \mathrm{E}$ (von Helmholtz 1863, appendix). $A^{\prime}$ is the 'occipital point'. The occipital point is a point behind the observer. The occipital point is exactly in the direction opposite to the primary position. From Southall, 1937.

positions of gaze (Fig. 8). Moreover, all horizontal direction circles intersect all vertical direction circles perpendicularly. The proof of this (Fig. 9) is relatively straightforward. Interestingly, Donders' pupil Küster (1876) showed, using an arc with an array of sparks in the dark, that the direction circles are perceived as straight lines. This is probably caused by the fact that the horizontal and vertical direction circles intersect perpendicularly, and that they always conform to the horizontal and vertical meridian of the retina: if a line is horizontal everywhere in space, the brain apparently interprets the line to be straight. In the experiments of Küster, a meridian arc (that is projected onto the retina as a straight line) was perceived as curved in tertiary positions of gaze! A more or less similar experiment was done a century later by Nakayama and Balliet (1977): they found that a test-stripe presented in tertiary positions of gaze was set 'vertical' in the dark according to the direction of the direction circles. The perception of the angles of the intersections of horizontal and vertical direction circles being perpendicular is not a 'perceptual illusion' as Held (1970) believed; it really is true! For clinical use as coordinates, the circles can be projected on a frontoparallel screen as hyperbolas having half the curvature of those of the Hess screen.

The direction-circle coordinate system is preferable to the other systems because (1) the direction of the lines represent true horizontal and vertical 


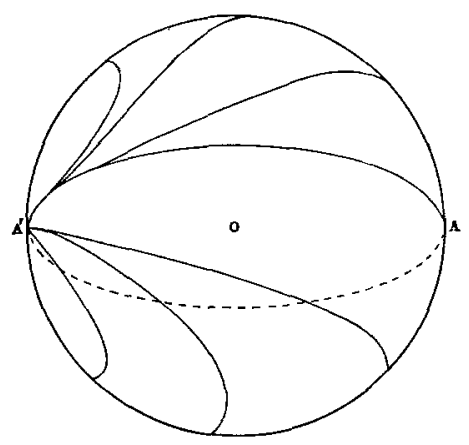

Fig. 7. A family of direction circles. The observer is at point $\mathrm{O}$, looking in primary position at point $\mathrm{A}$. All direction circles go through the occipital point $\mathrm{A}^{\prime}$. The occipital point is a point behind the observer. The occipital point is exactly in the direction opposite to the primary position. Here, one series of direction circles is shown with a common tangent through the occipital point. The coordinate system proposed by Kolling and Simonsz, based on the direction circles, consists of projections on a screen of a series of horizontal and a series of vertical direction circles. From Southall (1937).

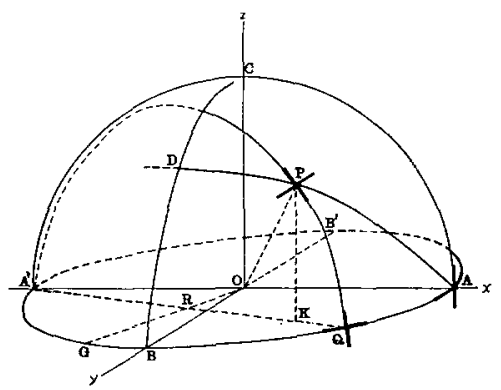

Fig. 8. 3-D drawing of the eye movement described in Fig. 6. $\mathrm{A}$ is primary position, $\mathrm{A}^{\prime}$ is the occipital point and $O$ is the observer. When the observer shifts his gaze from $Q$ to $P$ following the vertical meridian of his retina, the path followed will be a direction circle with $O G$ as axis of rotation. The horizontal and vertical retinal meridians are represented by the cross. Note that the direction of the cross follows that of the direction circle: no pseudotorsion occurs.

in tertiary positions of gaze, (2) all intersections are perceived by the observer as rectangular, (3) it is free of Listing's pseudotorsion and (4) the artefact vertical or horizontal deviations that occur using the Major Amblyoscope or Synoptometer, when there is a large horizontal and vertical angle of squint, are avoided.

\section{Note added in proof}

Tweed et al. (1990) have recently published an excellent account on the use of quaternions in describing eye rotation, to get rid of pseudotorsion. There are interesting parallels between the direction circles and quaternions that will need more study. 


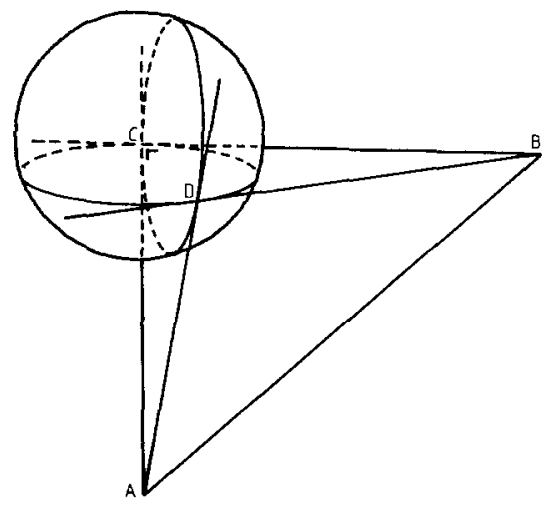

Fig. 9. Proof that all direction circles intersect perpendicularly. Point $\mathrm{C}$ is the occipital point. If the circles intersect perpendicularly at $C$, they also intersect perpendicularly at $D$, because triangle $\mathrm{ABC}$ and $\mathrm{ABD}$ are congruent ( 3 equal sides).

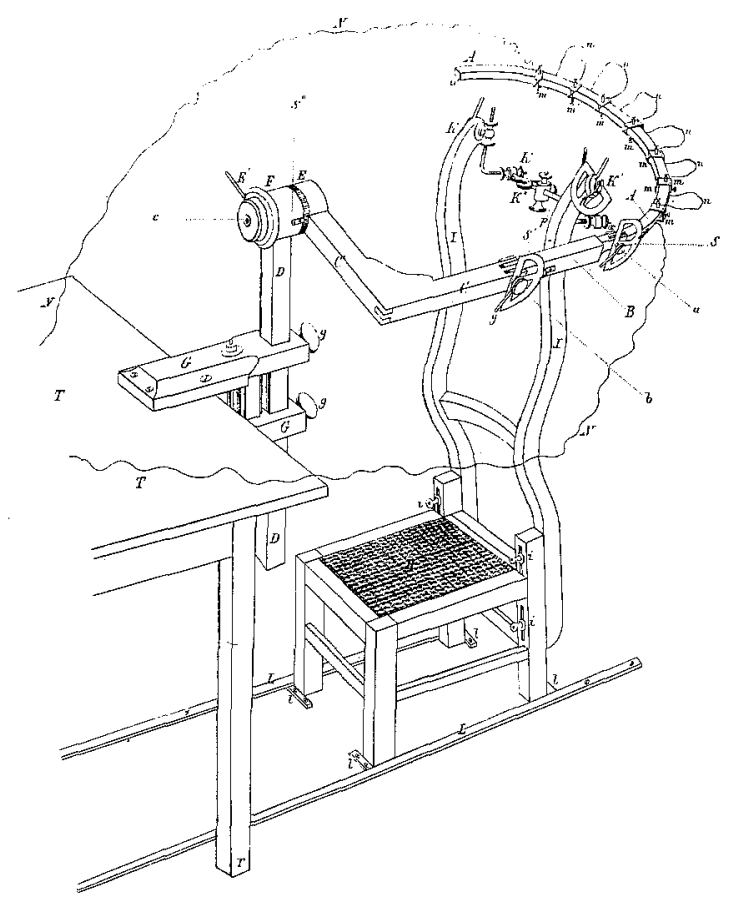

Fig. 10. The observer in Küster's experiments (1876) looked in the dark at an array of sparks $(\mathrm{m})$, on an are that could tilt like a meridian arc at hinge a, but also like a direction circle at hinge $b$. The observer sat on the chair 'the wrong way around', his head being fixed with biteboard $\mathrm{K}$. A meridian arc (that is projected onto the retina as a straight line) was perceived as curved outwards in tertiary positions of gaze, a direction circle was perceived as straight! 


\section{Acknowledgements}

This work was supported by a fellowship of the Royal Netherlands Academy of Arts and Sciences (Dr Simonsz). We wish to thank Dr G. Dagnelie for providing the proof presented in Fig. 9.

\section{References}

Baumeister E. Klinische mededeelingen. III. Invloed van de houding van het hoofd bij de gezichtsscherpte bij nystagmus. Jaarlijksch verslag betrekkelijk de verpleging en het onderwijs in het Nederlandsch Gasthuis voor Ooglijders, 15, wetenschappelijke bijbladen (Fifteenth yearly report concerning nursing and education in the Netherlands Ophthalmic Hospital, Scientific suppl.), ed.: Donders FC. Van de Weijer, Utrecht, 1874; 71-73.

Baumeister E. Klinische mededeelingen. IV. Bijdrage tot de diagnose der trochlearisverlamming. Jaarlijksch verslag betrekkelijk de verpleging en het onderwijs in het Nederlandsch Gasthuis voor Ooglijders, 15, wetenschappelijke bijbladen, ed.: Donders FC. Van de Weijer, Utrecht, $1874 ; 73-76$.

Donders FC, Physiologische en pathologische aanteekeningen van gemengden aard, IV: De beweegingen van het menselijk oog. Ned Lancet 1846; 2: 104-158.

Donders FC. Beiträge zur Lehre von den Bewegungen des menschlichen Auges. Holländische Beiträge Anat Physiol Wiss, 1848; 1: 105-45.

Donders FC, Doijer D. De ligging van het draaipunt van het oog. Jaarlijksch verslag betrekkelijk de verpleging en het onderwijs in het Nederlandsch Gasthuis voor Ooglijders, 3, wetenschappelijke bijbladen, ed.: Donders FC. Van de Weijer, Utrecht, 1862; 210-28.

Donders FC. Die Bewegungen des Auges, veranschaulicht durch das Phaenophthalmotrop. Arch f Ophthalmol 1870; 16(1): 154-75.

Donders FC. Über das Gesetz der Lage der Netzhaut in Beziehung zu der der Blickebene. Arch f Ophthalmol 1875; 21: 125-30.

Donders FC. Versuch einer genetischen Erklärung der Augenbewegungen. Pflügers Arch Physiol 1876; 13: 373-421.

Fick A. Die Bewegungen des menschlichen Auges. Zeitschr f rat Med 1854; 4: 101-28.

Fisher MH. Beiträge und kritische Studien zur Heterophoriefrage auf Grund systematischer Untersuchungen. Alb v Graefes Arch f Ophthalmol 1922; 108: 251-84.

Harms H. Über die Untersuchung von Augenmuskellähmungen. Graefes Arch Ophthalmol 1941; 144: 129-49.

Held R. Two modes of processing spatially distributed visual stimulation. In: The neurosciences, second study program, ed: Schmitt FO. Rockefeller University Press, New York, 1979; $317-24$.

von Helmholtz $\mathbf{H}$. Über die normalen Bewegungen des menschlichen Auges. Graefes Arch Ophthalmol 1863; 9(2): 153-214.

von Helmholtz H. Handbuch der Physiologischen Optik, Vol 3. 3rd ed, Leopold Voss, Hamburg \& Leipzig, 1910.

Hering E. Die Lehre vom binocularen Sehen. Wissenschaftliche Abhandlungen, Band 2. Engelmann, Leipzig, 1868.

Hess WR. Ein einefaches messendes Verfahren für Motilitätsprüfung der Augen. Zeitschr $f$ Augenheilk 1916; 35: 201-19.

Hoffmann FB, Bielschowsky A. Die Verwerthung der Kopfneigung zur Diagnostik von Augenmuskellähmungen aus der Heber- und Senkergruppe. Alb v Graefes Arch f Ophth 1900; 51: 174-185. 
Hueck. Die Achsendrehung des Auges. Dorpat, 1838.

Hunter J. The use of the oblique muscles. In: Observations on certain parts of the animal oeconomy. London, 1786.

Kolling GH, Simonsz HJ, van Dijk B. Die Bedeutung des Koordinatensystems für die Motilitätsdiagnostik. In: Augenbewegung und visuelle Wahrnehmung, Proc 1st Symp Bielschowsky- Gesellschaft f Schielforschung, ed: Mühlendyck H, Göttingen, October 1986. Enke Verlag, Stuttgart, 1989.

Küster F. Die Direktionskreise des Blickfeldes. Arch f Ophthalmol 1876; 22(1): 149-210.

Listing JB. Beitrag zur physiologischen Optik. Göttinger Studien. Göttingen, Vandenhoeck and Ruprecht, 1845.

Nagel A. Über das Vorkommen von wahren Rollungen des Auges um die Gesichtslinie. Alb v Graefes Arch f Ophth 1871; 17: 237-64.

Nakayama K, Bailliet R. Listing's Law, eye position sense, and perception of the vertical. Vision Res 1977; 17: 453-57.

Ruete CGT. Das Ophthalmotrop, dessen Bau und Gebrauch. Göttinger Studien. Göttingen, Vandenhoeck und Ruprecht, 1845.

Ruete CGT. Lehrbuch der Ophthalmologie. Braunschweig, 1846; 2nd edition, Vol. 1, 1853; $36-37$.

Ruete CGT. Leerboek der Ophthalmologie, in het Nederduitsch bewerkt en van aanteekeningen voorzien door dr. Donders, off. v. gen. der tweede klasse bij 's Rijks kweekschool voor militaire geneeskundigen. Utrecht, C. v.d. Post Jr, Amsterdam, C.G. v.d. Post, 1846.

Ruete CGT. Ein neues Ophthalmotrop, zur Erläuterung der Functionen der Muskeln und brechenden Medien des Menschlichen Auges. Leipzig, Teubner, 1857.

Schubert G. Studien über das Listingsche Bewegungsgesetz am Auge. I. Mitteilung. Pflügers Arch Physiol 1924; 205: 637-68.

Schubert G. Studien über das Listingsche Bewegungsgesetz am Auge. II. Mitteilung. Pflügers Arch Physiol 1927; 215: 553-87.

Simonsz HJ. Investigations of ocular counterrolling and Bielschowsky head-tilt test, stiffness in passive ocular rolling and displacement of recti eye muscles. PhD Thesis, University of Amsterdam, 1984.

Simonsz HJ. The mechanics of squint surgery: Length-tension measurements of human eye muscles, their implementation in a computerized model, and analysis of squint surgery with the model. Habilitionsschrift (thesis) University of Giessen, to appear in Acta Strabologica C.E.R.E.S.(Dr J.B. Weiss), Paris, 1990.

Southall JPC. Introduction to physiological optics. Dover Publications, New York, 1937.

Tweed D, Cadera W, Vilis T. Computing three-dimensional eye position quaternions and eye velocity from search coil signals. Vision Res 1990; 30: 97-110.

Tweed D, Vilis T. Geometric relations of eye position and velocity vectors during saccades. Vision Res 1990; 30: 11-127.

Volkmann AW. Über die Mechanika der Augenmuskeln. Ber Verh Sachs Wsch 1869; 21: $28-69$.

Wundt W. Ueber die Bewegung der Augen. Arch f Ophthalmol 1862; 8(2): 1-87.

Wundt W. Beschreibung eines künstlichen Augenmuskelsystems zur Untersuchung der Bewegungsgesetze des menschlichen Auges im gesunden und kranken Zustande. Alb v Graefes Arch Ophthalmol 1862; 8(2): 88-114.

Address for correspondence: H.J.Simonsz, Netherlands Ophthalmic Research Institute, P.O. Box 12141, 1100 AC Amsterdam, The Netherlands. 